Studia nad Autorytaryzmem i Totalitaryzmem 43, nr 2

Wrocław 2021

https://doi.org/10.19195/2300-7249.43.2.6

\author{
RYSZARD SKARZYŃSKI \\ ORCID: 0000-0001-5669-0731 \\ Uniwersytet w Białymstoku \\ r.skarzynski@uwb.edu.pl
}

\title{
Internacjonalizacja. W kręgu nowej terminologii dwudziestowiecznej debaty ideologicznej i naukowej ${ }^{*}$
}

Słowa kluczowe: internacjonalizacja, stosunki międzynarodowe, nauka o polityce, państwo narodowe, globalizacja, poliarchia.

\author{
INTERNATIONALIZATION: ABOUT THE NEW TERMINOLOGY \\ OF THE TWENTIETH-CENTURY IDEOLOGICAL AND SCIENTIFIC DEBATE
}

\begin{abstract}
There are many specific concepts used in social sciences to describe social phenomena. In this text, the subject of research is internationalization, one of the new terms in the twentieth century, similarly to fascism, communism, authoritarianism, totalitarianism, the political, geopolitics, but also international relations and polyarchy. The article presents the meaning of the concept of internationalization, its genesis and relationships with specific social phenomena to which it should be applied during analysis.

Keywords: internationalization, international relations, political science, nation state, globalization, polyarchy.

* Mój tekst stanowi wyraz szacunku i podziękowania dla Profesora Marka Maciejewskiego, który przez blisko dwadzieścia lat (dokładnie od konferencji w Świeradowie Zdroju, 16-19 października 2001 roku) zapraszał mnie do udziału w wielu organizowanych przez siebie wydarzeniach i inspirował do pisania kolejnych artykułów na najrozmaitsze tematy, od demokracji medialnej i totalitaryzmu po problematykę teorii prawa. Bez Niego te teksty niewątpliwie by nie powstały, a przecież ściśle łączą się one z kolejnymi ważnymi etapami w moim rozwoju naukowym. Szkoda, że ten mały jubileusz przypadł na moment, jak mi się zdaje, ostatecznego upadku europejskiego uniwersytetu z jego wspaniałymi zwyczajami, ale przecież nie wybieramy sobie czasu naszej aktywności.
\end{abstract}


W XX wieku pojawiło się wiele terminów, które zostały sformułowane, aby zlokalizować, opisać i ocenić liczne zjawiska społeczne, dotychczas nierozpoznane, jawiące się jako nowe, niezrozumiałe czy nawet groźne. Nierzadko stały za nimi mniej lub bardziej poważne teorie, których założenia i treść rozważano przez dziesięciolecia. Wśród nich trzeba przede wszystkim wymienić: faszyzm, komunizm, autorytaryzm, totalitaryzm, to, co polityczne, geopolitykę, ale także stosunki międzynarodowe i poliarchię. Związane są z nimi pojęcia pochodne, często używane intuicyjnie i, nawet w przypadku poważnych badaczy, bez głębszej refleksji.

W tekście tym chciałbym pochylić się nad właśnie takim, dość szczególnym, pochodnym pojęciem, a mianowicie nad internacjonalizacją. Wydaje się, że jego znaczenie naukowe może być znacznie szersze, aniżeli się często przypuszcza - zwłaszcza jeśli pominie się publicystyczne, a w istocie potoczne użycie tego słowa.

\section{Geneza problemu}

O ile nad faszyzmem, autorytaryzmem i totalitaryzmem debatowano głównie w kontekście zagrożeń dla wolności, cywilizacji, liberalizmu i demokracji, o tyle problematyka stosunków międzynarodowych, systemu międzynarodowego i internacjonalizacji dotyczyła kwestii związanych z organizacją ludzkich społeczeństw, z procesami przebiegającymi w wielkich strukturach społecznych i w relacjach między państwami, także w interakcjach globalnych. Napotykamy tu mniej emocji, debata nie była tak szeroka i, jak się okazuje po latach, nie była też przez to bardziej wnikliwa. W literaturze z zakresu stosunków międzynarodowych doktrynerstwa - w złym znaczeniu tego słowa - nie brakuje ${ }^{1}$.

Termin ,internacjonalizacja”, także w naukach społecznych, został obecnie w znacznej mierze zastąpiony przez pojęcie globalizacji. Internacjonalizacja stała się natomiast przedmiotem dyskusji w ekonomii ${ }^{2}$ — znacznie szerszej i o wiele bardziej wnikliwej aniżeli rozważania zawarte w publikacjach internacjologów. Kompleksy polskiej nauki, a może bardziej krajowych polityków, ujawniają się w debacie nad pozornym problemem internacjonalizacji nauki i szkolnictwa wyższego ${ }^{3}$. Podejmujący ją zupełnie nie zdają sobie sprawy z tego, że chodzi

${ }^{1}$ Szerzej zob. R. Skarzyński, Od statusu uczonego do funkcji ideokopiarki. Jak uniwersyteccy profesorowie daja się przeksztatcać w środek polityczny i rujnuja własna dyscyplinę, powielajac zachodnie wizje rzeczywistości międzynarodowej, [w:] Wokót teorii stosunków międzynarodowych, red. W. Mich, J. Nowak, Lublin 2012, s. 19-82.

2 Zob. na przykład Internacjonalizacja przedsiębiorstw: uwarunkowania, procesy, wyniki badań, red. B. Glinkowska-Krauze, Łódź 2016.

${ }^{3}$ Zob. Internacjonalizacja polskich ośrodków politologicznych, red. T. Domański, A. StępieńKuczyńska, A. Frykowska, Łódź 2017. 
tutaj o globalizację, czyli rozwój interakcji społecznych i współzależności, dla których granice państw mają coraz mniejsze znaczenie. Te procesy w ogromnej mierze wpływają na ewolucję instytucji naukowych, pod znakiem zapytania stawiając funkcjonowanie tradycyjnego uniwersytetu, a zwłaszcza wydziałów nauk społecznych.

W tym kontekście należy przede wszystkim podkreślić, że globalizacja jest czymś zupełnie innym aniżeli internacjonalizacja. Internacjonalizacja wiąże się z triumfem wizji wspólnot narodowych, podziałami, granicami, kontrolą partycypacji i ograniczeniami interakcji między rozmaitymi podmiotami, poddanymi rządom realizującym interesy narodowe. Globalizacja jest procesem uniwersalnym, który to wszystko osłabia, a nawet znosi, łączy ludzi w przestrzeni i stawia przed nowymi wyzwaniami, gdy współpraca i konkurencja stają się coraz bardziej bezpośrednie i szybko się zmieniają. Globalizacja podważa pozycję państwa narodowego i w dłuższej perspektywie będzie ten typ państwa osłabiać, a nawet eliminować, podczas gdy internacjonalizacja prowadziła do jego rozwoju i dominacji.

W nauce o stosunkach międzynarodowych internacjonalizacja pojawia się na obrzeżach refleksji ${ }^{4}$. Badacze stosunków międzynarodowych jakby nie chcieli się tym problemem zajmować. Tymczasem za tym terminem kryją się doniosłe treści, zwłaszcza w kontekście zjawisk politycznych, związanych z organizacją ludzkich społeczeństw i funkcjonowaniem państw. Są one ważne także dla naszego rozumienia procesów historycznych. Przy ich pomocy możemy bardziej wnikliwie opisać szereg zmian społecznych zachodzących we współczesnym świecie, podczas gdy słowo „globalizacja” służy raczej do lokalizacji zmian poddawanych ocenie wartościującej i lokalizacji zagrożeń.

\section{Państwo narodowe i niektóre skutki jego powstania}

Jedną z podstawowych tez badaczy rzeczywistości społecznej w skali systemów państw, ich globalnej koegzystencji i rywalizacji, stało się w XX wieku twierdzenie, że współczesny świat podlega internacjonalizacji. Stanowiło ono efekt wzrostu zainteresowania środowiskiem funkcjonowania politycznych jednostek terytorialnych, a potem ich interakcjami i systemem związków między nimi. W coraz większym stopniu dostrzegano bowiem skutki wciąż bardziej złożonych i kompleksowych zależności zachodzących między tego typu podmiotami, wywołujących daleko idące konsekwencje dla funkcjonowania współczesnych społeczeństw i próbowano je wyjaśnić przy pomocy teorii.

${ }^{4}$ Zob. na przykład J. Kent, The Internationalization of Colonialism. Britain, France and Black Africa, 1939-1956, Oxford 1992. 
Rozpatrywana z niezbyt wnikliwej perspektywy nauki o stosunkach międzynarodowych internacjonalizacja jest procesem społecznym, który stanowi siłę napędową rozwoju stosunków międzynarodowych. Polega on przede wszystkim na wzroście znaczenia relacji między państwami i narodami, w efekcie czego coraz więcej obszarów życia społecznego znajduje się pod ich wpływem i dochodzi do nasilenia intensywności wzajemnych oddziaływań zarówno poszczególnych narodów i państw, jak i rozmaitych dziedzin ich życia ${ }^{5}$.

Paradoksalnie termin ten dzisiaj w politologii i nauce o stosunkach międzynarodowych jest już nieco zapomniany. Stało się tak być może dlatego, że w ramach tej refleksji nie udało się precyzyjniej określić procesów internacjonalizacji. Wprawdzie jeden z wczesnych propagatorów tego terminu pisał nawet o prawie internacjonalizacji, jednak faktycznie w swoich rozważaniach nad nim ograniczał się do wyliczenia i opisu zjawisk gospodarczych, politycznych i kulturowych (w tym prawnych) i nigdy nie zbudował zespołu twierdzeń przydatnych do ich wyjaśnienia ${ }^{6}$. Sformułowanie takiej teorii okazało się wówczas zbyt trudne.

Czy jednak dzisiaj nie jest możliwe głębsze teoretyczne wyjaśnienie procesu internacjonalizacji? Kilkadziesiąt lat później dysponujemy przecież znacznie większą wiedzą. Na ile jest to termin nadal adekwatny, pomocny w wyjaśnianiu zjawisk społecznych? Zjawisk doniosłych, jeśli zdać sobie sprawę z tego, że procesy internacjonalizacji objęły cały gatunek ludzki i określiły jego funkcjonowanie.

Na początku możemy pokusić się o prostą definicję, która pokazuje przedmiot badania i określa kierunek poszukiwań. Internacjonalizacja znaczy tyle, co umiędzynarodowienie, czyli proces uzależniania różnorakich zjawisk społecznych od skutków relacji rozwijających się między państwami narodowymi (zjawisk dotychczas autonomicznych wobec stosunków zachodzących między nimi), gdy ich interakcje w czasie ulegają wydłużeniu, intensyfikacji i zyskują na znaczeniu, ponieważ kontrolują one coraz więcej obszarów życia społecznego. W efekcie to, co się dzieje w obrębie politycznej organizacji terytorialnej stopniowo coraz bardziej zależy od jej relacji z innymi tego rodzaju bytami, a także od procesów, które zachodzą w ich wnętrzu (tych innych podmiotów, z którymi ona wchodzi w stosunki niezależnie od tego, czy ich chce, czy unika). Wszystkie te procesy modyfikują relacje między nimi.

Ważne jest uświadomienie sobie, że — wbrew opinii Józefa Kukułki — problemem badawczym nie są tutaj stosunki państw i narodów, choćby dlatego, że te ostatnie są zbiorowościami niezdolnymi do rozwijania jakichkolwiek interakcji $^{7}$. Narody, z racji swoich cech, jako zbiorowości nie były, nie są i nie będą uczestnikami stosunków nazywanych międzynarodowymi. „Stosunki międzynarodowe" to termin o charakterze metafory, powstały i upowszechniony w epoce

5 J. Kukułka, Teoria stosunków międzynarodowych, Warszawa 2000, s. 179-186.

6 Ibidem, s. 186-192.

7 Szerzej zob. R. Skarzyński, Stosunki międzynarodowe, system międzynarodowy i poliarchia, „Stosunki Międzynarodowe” 2010, nr 1-2, s. 12-14. 
dynamicznego rozwoju świadomości narodowej — głównie zresztą świadomości elit politycznych i intelektualnych najbardziej rozwiniętych społeczeństw. Pewne jednak elementy kultury tych elit (z biegiem czasu, w efekcie rozwoju edukacji, wpajane szerszym kręgom społecznym), zwłaszcza zaś idea narodowości i związane z nią ambicje do kształtowania porządku świata (występujące w różnych wariantach w postaci wizji porządku narodowego, a potem międzynarodowej wspólnoty państw), skutecznie pełnią funkcję mobilizującą ludzi do działania w wielu formach. Przede wszystkim do działania politycznego, gdy lokalizuje się wroga i przejawia zdolność uderzenia w niego każdym środkiem.

Relacje między państwami i narodami są możliwe do badania jedynie w kontekście procesów tworzenia państw narodowych. Nie należy jednak tego zjawiska rozumieć dosłownie, w sposób potoczny. W przypadku państw narodowych nie chodzi o narody, ale o organizacje, które posługują się wizjami narodowymi i podejmują działania mające na celu powołanie państwa narodowego, a potem prowadzą jego politykę. Tylko takie rozróżnienie pozwoli nam zrozumieć, czym są stosunki międzynarodowe - zjawisko ograniczone w czasie i bardzo specyficzne, nawet jeśli miało ogromy wpływ na ukształtowanie wielu fundamentalnych cech współczesnego świata. Taka wykładnia problemu umożliwia też zrozumienie fenomenu państw wielonarodowych i skupiających zbiorowości, które nie zyskały statusu narodu.

Czym są więc stosunki międzynarodowe? Precyzyjna odpowiedź na to pytanie ma kluczowe znaczenie dla sformułowania teorii internacjonalizacji. Łatwo dostrzec, że zjawisko stosunków międzynarodowych jest obecnie znacznie szersze od zjawiska stosunków międzypaństwowych. Gdy jednak przyjrzymy się historii naszego gatunku, widzimy jak bardzo jest ono ograniczone w czasie.

Gdy uważnie zbadamy historię powszechną przynajmniej ostatnich kilkuset lat, łatwo dojdziemy do wniosku, że stosunki międzynarodowe nie są stosunkami ani narodów, ani państw, a powstały w efekcie ukształtowania się specyficznych bytów: państw narodowych. Ich uczestnikami nie są jednak tylko państwa narodowe, ale wiele podmiotów zdolnych przenikać granice państwowe i rozwijać struktury istniejące niejako ponad tymi granicami. Specyfikę stosunków międzynarodowych określa jednak obecność państw narodowych, nierozerwalnie związanych z ich pojawieniem się i rozwojem.

Internacjonalizacja jest procesem społecznym przejawiającym się w:

- przyjmowaniu przez państwa wizji narodowych, nawet jeśli ich terytorium nie jest zamieszkiwane przez naród, tylko przez rodziny i plemiona;

— rosnącej liczbie terytorialnych politycznych zjednoczeń ludzi, których stosunki stają się coraz bardziej złożone i podlegają intensyfikacji;

— rozwoju interakcji między tymi podmiotami w systematycznie rosnącej przestrzeni, kontynentalnej, międzykontynentalnej, a potem w skali globalnej;

— wzrastającej liczbie podmiotów przekraczających granice państw narodowych; 
- włączaniu w obszar oddziaływania stosunków państw narodowych rosnącej liczby podmiotów i zjawisk społecznych, w tym różnorakich organizacji i korporacji;

— wchodzeniu podmiotów niepaństwowych w interakcje z rządami państw narodowych, przy czym czas trwania, intensywność i znaczenie tych interakcji ciągle rosną;

— rosnącym uzależnieniu poziomu życia ludzi od ich uczestnictwa w stosunkach międzynarodowych;

— rosnącym uzależnieniu kultury od coraz bardziej zintensyfikowanych interakcji związanych z przekraczaniem granic państw.

Na przebieg stosunków międzynarodowych najsilniej oddziałują państwa narodowe, ale na ich interakcje rosnący wpływ zdobywają różnorakie organizacje polityczne, gospodarcze i kulturowe - od stowarzyszeń ludowych, przez korporacje, związki sportowe, aż po organizacje terrorystyczne, które chcą obalenia istniejącego ładu. Niektóre z nich mają charakter narodowy, ale większość jest pozbawiona cech narodowościowych. Uczestniczą one w stosunkach międzynarodowych, kiedy przekraczają granice państw narodowych. Na sposób ich istnienia i działania wielki wpływ mają ambicje i roszczenia władz państw narodowych, które próbują je kontrolować i wykorzystać ekonomicznie. Z drugiej strony możliwe staje się rozwijanie działalności gospodarczej i kulturowej przez oddziaływanie na interakcje państw.

Internacjonalizacja dotyczy zatem etapu historii gatunku ludzkiego związanego $\mathrm{z}$ istnieniem państw narodowych. Stanowi on aktualnie ostatni, i na dodatek bardzo krótki, okres historii grupowania naszego gatunku w terytorialne podmioty polityczne, nazywane przez nas państwa mi, odkąd zaczęły artykułować swoją tożsamość za pomocą wizji narodowych.

Gdy bliżej zbadamy pojęcie internacjonalizacji, nieuchronnie pojawia się pytanie o to, co było wcześniej. Jak określić stosunki zachodzące między państwami i innymi ich uczestnikami przed pojawieniem się państw narodowych i zapoczątkowaniem procesu internacjonalizacji? Czy wystarczy nazwać je stosunkami międzypaństwowymi?

\section{Zakres czasowy internacjonalizacji}

Państwa narodowe nie wzięły się z niczego i nie powstały od razu. Elementarna znajomość historii powszechnej wskazuje, że były one produktem kierunkowej ewolucji społecznej, która prowadziła do wyłaniania coraz bardziej kompleksowych, potężniejszych zjednoczeń ludzi ${ }^{8}$, zdolnych kontrolować coraz większe

8 Zob. O. Brunner, Land und Herrschaft, Wien 1966; P. Kennedy, Mocarstwa świata, Warszawa 1994; M. Creveld, The Rise and Decline ot the State, Cambridge 1999. 
zasoby i przetwarzać je na energię ${ }^{9}$ W ich rozwoju ogromną rolę odegrały nie tylko wzrost populacji ludzkiej i rozwój technicznych środków walki, ale także wizje integrujące ludzi i pozwalające im uderzyć w rywali jako jednorodne zjednoczenie.

Państwa narodowe wyłoniły się po upadku państw dynastycznych w efekcie ciągu rewolucji społecznych, jakie miały miejsce w okresie od XVII do XX wie$\mathrm{ku}$ - zainicjowanych w Europie, a potem także na innych kontynentach. Istotny wpływ na umocnienie państw narodowych, na stworzenie przez nie systemu globalnego, miał rozkład porządku kolonialnego, w efekcie którego powstały państwa określające swoją tożsamość na podobieństwo państw europejskich, nawet jeśli nie zamieszkiwały $\mathrm{w}$ nich zbiorowości jakkolwiek przypominające narody — jak jest jeszcze dzisiaj w niemałej liczbie państw Afryki i Ameryki Południowej. Pomimo tego obecnie prawie wszystkie państwa świata określają swoją tożsamość w kontekście narodowym i starają się o przynależność do wspólnoty narodów. Funkcjonowanie poza nią jest zawsze efektem specyficznych procesów wykluczenia, nie z powodów gospodarczych czy kulturowych, ale politycznych, gdy mamy do czynienia z silnymi sprzecznościami interesów.

Stosunki międzynarodowe były poprzedzane przez stosunki innego typu, realizowane przez podmioty, które odmiennie określały swoją tożsamość. Ich uczestnikami były nie tylko państwa, ale także struktury już dzisiaj niewystępujące albo znajdujące się w odmiennym formach i pełniące zupełnie inne funkcje.

W czasach poprzedzających dominację państw narodowych zdecydowanie większa rola przypadała chociażby miastom, zdolnym wywierać niespotykany już dzisiaj wpływ w wielkiej przestrzeni i tworzyć potężne związki, jak Liga Lombardzka i Hanza. Ogromną rolę odgrywały przede wszystkim jednak wielkie rody. Ich koalicje były zdolne wchodzić w stosunki wykraczające poza granice terytorialnych związków politycznych. Powstała we Francji w XVI wieku Liga Święta była w znacznej mierze koalicją rodzin katolickich, walczącą z hugenotami za pomocą środków pozyskanych z Madrytu. W XVII wieku na obszarach Rzeszy starł się związek katolickich książąt z unią książąt protestanckich.

W tamtych czasach nie istniało pojęcie narodu. Tożsamość określała głównie świadomość obecności dynastii Habsburgów, Burbonów, Wittelsbachów, Jagiellonów i wielu innych, na czele których stali namaszczeni i nienamaszczeni przywódcy, czyli królowie i książęta. W znacznie mniejszym zakresie przesądzało o niej zamieszkiwanie w wielkich i potężnych miastach, jak Wenecja, Nowogród czy Dubrownik, ponieważ podejmowane w nich próby wytworzenia wizji powszechnego porządku niezmiennie kończyły się fiaskiem. Stało się tak nawet w przypadku tak wielkiej potęgi, jaką była Wenecja ${ }^{10}$. Tutaj wielu dożów próbowało założyć dynastie, ale zawsze kończyło się to dla nich bardzo źle, a często nawet tragicznie, gdy tracili życie.

9 V. Smil, Energy in World History, Boulder 1994.

10 D. Rosand, Mythos of Venice. Chapel Hill 2001, s. 6-46; A. Landwehr, Die Erschaffung Venedig. Raum, Bevölkerung, Mythos 1570-1750, Paderborn 2007, s. 334-407. 
W państwach rządzonych przez dynastie liczyła się głównie obecność władcy, który uzyskał status świętego i był traktowany jako reprezentant Boga na Ziemi. Jego boskie właściwości odbierano jako gwarancję opieki, bezpieczeństwa i pomyślności ${ }^{11}$. Obecność księcia, a jeszcze lepiej króla lub cesarza, była dla ludzi warunkiem pomyślności i w ogóle uporządkowanej egzystencji z pokolenia na pokolenie.

Bez uwzględnienia tych elementarnych faktów nie da się zrozumieć ani zjawiska stosunków międzynarodowych, ani procesu internacjonalizacji. Konieczne jest dostrzeżenie kluczowego procesu zmian kulturowych i politycznych, które umożliwiły rozwój internacjonalizacji.

Po upadku Cesarstwa Rzymskiego w Europie powstał stan anarchii, w wyniku którego dominujące pozycje, o charakterze potęg zdolnych kontrolować terytoria, zdobyły plemiona koczowników, a potem niektóre miasta i rody. Niekiedy kontrolę nad terytoriami przejmowały nawet grupy awanturników, rywalizujących między sobą. Część tych podmiotów wychodziła z walki zwycięsko, pomnażając zasoby. Inne wcześniej czy później upadały, stając się łupem zwycięzców. Ten proces głęboko sięgającej selekcji rozciąga się na kolejne stulecia, a faktycznie trwał ponad tysiąc lat. Europa, a w istocie cała Eurazja, XVII wieku była już przestrzenią terytorialnie podzieloną i uporządkowaną, zdominowaną przez wielkie rody, którymi kierowali władcy dysponujący statusem świętych.

Kongres kończący w 1648 roku wojnę trzydziestoletnią, często niesłusznie prezentowany jako początkowy akt epoki nowoczesnych stosunków międzynarodowych, był konferencją władców rozstrzygających o tym, co dzieje się w jednym z głównych centrów tej przestrzeni ${ }^{12}$. Miał miejsce nie w momencie zainicjowania stosunków międzynarodowych, lecz przypadł na finalną fazę rozkwitu władzy dynastycznej. Trzeba było jeszcze niemało zmian, aby królestwa przekształciły się w reżimy demokratyczne albo dyktatorskie, których podstawą funkcjonowania nie było już prawo boskie, lecz świeckie, stanowione i oparte na idei praw człowieka.

Dopiero na gruzach systemu prawa boskiego i władzy królewskiej powstały państwa narodowe, ale miejscami nawet już we wczesnym średniowieczu istniał system stosunków terytorialnych potęg politycznych, których uczestnikami były także inne podmioty, przede wszystkim gospodarcze, ale również kulturowe (organizacje religijne). We wczesnym średniowieczu niemałą rolę odgrywali piraci, a także waleczne i ruchliwe związki wojowników. Były to zarówno związki powstałe z rozpadu wojsk królewskich (słynna kompania kastylyjska przejęła Księstwo Aten i władała nim w latach 1311-1388 ${ }^{13}$ ), jak i o charakterze plemiennym (jak Waregowie, Wikingowie i Normanowie).

11 M. Bloch, Społeczeństwo feudalne, Warszawa 1981, s. 223-291; E. Kantorowicz, Dwa ciata króla, Warszawa 2007.

12 Szerzej zob. R. Skarzyński, Od statusu..., s. 15-23.

13 K. Setton, Catalan Domination of Athens 1311-1388, London 1975. Krótki opis tego ciekawego przypadku znaleźć można w: P. Edbury, Laciński Wschód 1291-1669, [w:] Historia kru- 
W tamtych czasach powstawały granice i polityczne potęgi terytorialne, które wchodziły we wzajemne stosunki dużo wcześniej, nim wyłoniły się w wielkiej przestrzeni struktury państw narodowych. Ten system i proces prowadzący do jego powstania wymagają nazwania i zbadania, także w kontekście genezy internacjonalizacji. Bez jego wyjaśnienia nie można bowiem zrozumieć zjawiska umiędzynarodowienia współczesnego świata.

Internacjonalizacja była kontynuacją procesów przebiegających wtedy, kiedy świadomość narodowa, tym bardziej zaś wizja narodowa i struktury przez nią uzasadniane, jeszcze nie istniały. Aby to zrozumieć, konieczne jest pochylenie się nad zjawiskiem państwa jako organizacji politycznej, która grupuje wielkie zbiorowości ludzi, wchodzi w kontakt nie tylko z innymi państwami, ale także podmiotami społecznymi nie dysponującymi jasno określonym statusem terytorialnym.

Państwo jest terytorialną organizacją polityczną. Nie istnieje jednak państwo jako takie - ponieważ jest ono efektem mobilizacji politycznej, zawsze jakaś wizja określa jego tożsamość i powoduje, że uchodzi ono za prawomocne. Kryje się za nią specyficzny system władzy. Możliwe jest istnienie wielu typów państw, które wyodrębnimy na przykład pod kątem uzasadnienia ideowego i prawnego albo klasy czy grupy rządzącej.

Do ciekawych wniosków prowadzi zbadanie państw w kontekście wizji określającej ich tożsamość, ujętej w postaci doktryny czy będącej jej rozwinięciem ideologii. Tak możemy pokazać odrębność państw teokratycznych i dynastycznych. W średniowieczu i pierwszych stuleciach czasów nowożytnych nie były to państwa narodowe (chociaż w takich państwach czasem mogą istnieć narody, jak ma to miejsce we współczesnym Iranie, który z pewnością obecnie nie jest państwem narodowym tylko teokratycznym, aczkolwiek zamieszkuje go naród Persów), ponieważ tożsamość określała wizja świata, w której centralną pozycję zajmują bogowie (lub Bóg), reprezentowani na Ziemi na przykład przez kapłanów. Oni rozstrzygają o tym, co jest właściwe i parają się rządzeniem. W drugim przypadku, państwa dynastycznego, pozycję kapłanów zajmuje przywódca dominującego rodu, który jest przedstawicielem bogów (lub Boga) i rządzi (on albo w jego imieniu i korzystając z jego uprawnień urzędnicy) jako ich reprezentant, natomiast władza przechodzi dopiero $\mathrm{w}$ wypadku jego śmierci na uprawnionego potomka.

Internacjonalizacja nie miała miejsca w czasach istnienia potężnych państw teokratycznych i dynastycznych. Zachodziły wtedy inne procesy związane z kształtowaniem się terytorialnych jednostek politycznych i ich wchodzeniem we wzajemne interakcje. Internacjonalizacja nie jest też efektem pojawienia się samych narodów, tylko skutkiem ukształtowania się państw określających swoją tożsamość poprzez odwołanie się do symboliki konkretnych narodów, z ich historią, dorobkiem kulturowym i gospodarką pozwalającą na rozwinięcie potęgi umożliwiającej polityczną kontrolę terytorium i rywalizację z innymi tego typu zjednoczeniami ludzi.

cjat, red. J. Ridley-Smith, Warszawa 2000, s. 326-327; N. Hooper, M. Bennett, Atlas sztuki wojennej w średniowieczu 768-1487, Warszawa 2004, s. 108-109. 
Innymi słowy, internacjonalizacja jest procesem zainicjowanym i rozwijającym się w efekcie wyodrębnienia się narodów, gdy pojawiły się związki polityczne głoszące, że reprezentują ich interesy. Były to przede wszystkim partie polityczne, które korzystając $\mathrm{z}$ energii społecznej wyzwolonej w efekcie emancypacji kolejnych klas społecznych i oddziaływania wizji narodowej, podjęły zadanie organizacji specyficznego państwa. Te z nich, które okazały się zdolne do kontrolowania terytorium i ustanowienia w jego obrębie potęgi rywalizującej z innymi tego typu podmiotami, wyszły zwycięsko z brutalnych procesów selekcji, jakie miały miejsce w fazie upadku systemu dynastycznego. Ich efektem były liczne wojny: w Europie związane z kształtowaniem pozycji Niemiec, czyli wojna prusko-austriacka, prusko-francuska i dwie wojny światowe, zaś w Azji i obu Amerykach dotyczące zrzucenia jarzma kolonialnego.

Tak więc internacjonalizacja jest procesem zapoczątkowanym w okresie schyłku państw dynastycznych, gdy władza sprawowana przez rody prowadzone przez ich koronowanych (i tym samym namaszczonych) przywódców nie była już w stanie realizować przewidzianych dla nich funkcji i została zastąpiona władzą wyłonioną przez związki określającymi swoją tożsamość wizjami narodowymi i zdolne kierować państwami, czyli przez partie polityczne.

\section{Internacjonalizacja i poliarchizacja}

Internacjonalizacja na płaszczyźnie systemu państw narodowych dokonała się stosunkowo szybko, ponieważ przebiegała i nadal zachodzi w społeczeństwach poddanych głębokim i radykalnym zmianom w wyniku rozwoju technologii, zwłaszcza pozwalających na masowe przetwarzanie zasobów na energię, które zmieniają styl życia, wpływają na wzrost populacji ludzkich, a także pozwalają korzystać ze środków walki umożliwiających masowe zniszczenie. Niedostępne były one w czasach dominacji państw dynastycznych, a bardzo mocno zmieniły świadomość ludzi, także ze względu na rozwój komunikowania masowego.

Wewnętrzne systemy polityczne państw narodowych okazały się dostosowane do wymagań nowej epoki, cechującej się niebywałym dynamizmem, przede wszystkim ekonomicznym, który zmieniał strukturę społeczną. Stara, skostniała władza dynastyczna nie była w stanie sprostać nowym wyzwaniom. Musiała odejść, a wraz z nią odszedł system państw dynastycznych, przez stulecia rozwijających coraz bardziej intensywnie wzajemne relacje. Na jego gruzach rozwinęły się procesy internacjonalizacji. Powstał współczesny system międzynarodowy, w dominujących mediach społeczeństw liberalnych ideologicznie określany jako „międzynarodowa wspólnota państw”. Rozumiana jest ona jako lepsza i uprawniona do przywoływania do porządku innych, słabszych związków państw, dalej zależnych od największych potęg. 
Przyglądając się bliżej procesom zachodzącym w okresie rewolucji nowożytnych, powiemy, że internacjonalizacja jest efektem kształtowania się zaawansowanego systemu państw, które wcześniej w inny sposób określały swoją tożsamość, odwołując się do rozmaitych wizji dynastycznych. Przez długi czas ich stosunki wzajemne rozwijały się w wymiarze lokalnym i regionalnym. Internacjonalizacja została zainicjowana wtedy, kiedy pojawiły się państwa narodowe. Stanowi ona kontynuację, z licznymi modyfikacjami, procesów polegających na kształtowaniu się systemu państw, który pozostaje pod wpływem rozwijających się przez stulecia stosunków kulturowych i gospodarczych (na nie także zwrotnie oddziałuje i modyfikuje je). Ten system państw jest przede wszystkim systemem politycznym, czyli układem zależności terytorialnie określonych zbiorowości ludzkich, zmobilizowanych w ramach organizacji dysponujących własną tożsamością, zdolnością kontroli i przetwarzania zasobów na energię i generowania tą drogą potęg, mogących przez to panować na określonym terytorium i przetrwać w układach sił regulujących rywalizację takich podmiotów.

Taki system polityczny, gdy rozpatrujemy go w dłuższej perspektywie czasowej (od początkowego okresu kształtowania się terytorialnych organizacji politycznych) nazywa się poliarchią. Zaczął on kształtować się na Bliskim Wschodzie około sześć tysięcy lat temu, w sprzyjającym rozwojowi organizacji społecznej i mobilizacji politycznej środowisku przyrodniczym Mezopotamii i Egiptu ${ }^{14}$. Powstał więc kilka tysięcy lat wcześniej niż system państwa narodowych.

„Poliarchia” to termin ukuty w starożytnej Grecji ${ }^{15}$, stosowany w tamtych czasach do charakteryzowania systemu miast-państw greckich, któremu Robert Dahl nadał zupełnie inne znaczenie w związku ze swoją wizją systemu politycznego nowoczesnego państwa ${ }^{16}$. Dahl zupełnie pominął kwestię tego, że pojęcie poliarchii w języku starożytnych Greków ściśle łączyło się z pojęciami a narchii i monarchii. Jest to już jednak kwestia zupełnie inna, związana przede wszystkim z tym, że wprowadził on ten termin do dyskusji ideologicznych, gdzie wiedza naukowa nie ma większego znaczenia, w refleksji liczy się natomiast realizacja aktualnych celów politycznych.

Nas interesuje poliarchia w znaczeniu nadanym temu terminowi przez starożytnych Greków, którzy rozumieli pod tym pojęciem zbiór terytorialnych organizacji politycznych, wchodzących z sobą w interakcje i tworzących układ wzajemnych zależności, który dzisiaj po prostu nazwalibyśmy systemem politycznym.

Sam proces kształtowania się poliarchii możemy nazwać poliarchizacją, a dokładniej poliarchizacją gatunku ludzkiego, czyli mobilizacją zbiorowości ludzkich w zjednoczenia kontrolujące terytoria przy wykorzystaniu wszystkich

14 R. Skarzyński, M. Wajzer, T. Staniucha, Mind and Vision. Social Evolution and the Origins of the Political, ,Social Evolution and History” 2016, nr 1, s. 126-163.

15 R. Skarzyński, Anarchia i policentryzm, Białystok 2006, s. 307-309.

16 R. Dahl, Polyarchy. Participation and Opposition, New Haven 1971. 
dostępnych środków we wzajemnej rywalizacji. Takie zjednoczenia podlegały mobilizacji w efekcie zbiorowego uczuciowego przeżywania przez ludzi specyficznych wizji, celem ustanowienia zawartego w nich modelu porządku w całym znanym świecie. Dotyczyło to porządku religijnego (żydowskiego, chrześcijańskiego, muzułmańskiego), dynastycznego (będącego swoistą modyfikacją wizji religijnej), rasowego, klasowego czy wreszcie narodowego.

Innymi słowy, internacjonalizacja to proces $\mathrm{w}$ ramach poliarchizacji, gdy dominująca rola przypada nie narodom i dowolnym państwom, ale politycznym jednostkom terytorialnym, określającym swoją tożsamość za pomocą wizji narodowej. Pozbawiły one pozycji przewodnich państwa teokratyczne, dynastyczne, a także rasistowskie i klasowe. Proces ten osiągnął szczególnie intensywną formę w XIX i XX wieku. Warto pamiętać, że Stany Zjednoczone mogły zostać państwem rasistowskim, natomiast Rosja i Chiny klasowym. Jako czynnik jednoczący zwyciężyła jednak w tych państwach, i w zdecydowanej większości pozostałych, wizja narodowa, ponieważ lepiej jednoczy ona ludzi, silniej koncentrując na sobie ich uczucia i reguluje relacje jednostek, grup i zbiorowości - nawet jeśli możliwe są jej skrajne, nacjonalistyczne warianty.

Mówiąc o internacjonalizacji, opisujemy tylko część zjawisk mających miejsce w ramach procesu poliarchizacji. Dotyczy to takich zjawisk, które rozwinęły się w ostatnim jego okresie, kiedy poliarchia została zdominowana przez państwa określające swoją tożsamość za pomocą wizji narodowej.

Jeśli chcemy głębiej zrozumieć obecne funkcjonowanie globalnego systemu państw oraz wszystkiego, na co mają wpływ ich relacje, powinniśmy mówić nie o systemie międzynarodowym, ale o poliarchii. Powinniśmy zatem badać nie tylko system interakcji państw narodowych od ich powstawania w XVIII wieku, ale przede wszystkim system polityczny całego gatunku ludzkiego od momentu jego zainicjowania, aż po czasy współczesne. Gdy wyłoniły się pierwsze zjednoczenia polityczne zdolne kontrolować terytorium i zaczęly rozwijać wzajemne stosunki, powstały wtedy zaczątki systemu politycznego państw o charakterze poliarchii.

Początkowo jego uczestnikami były państwa teokratyczne i miał on charakter lokalny. Jego elementy powstawały w różnych częściach świata, tam, gdzie sprzyjały warunki naturalne. Proces ten przebiegał aż do początków epoki kolonialnej. Podboje Europejczyków zainicjowały proces łączenia poliarchii lokalnych i regionalnych w jednolity system poliarchii globalnej.

Dopiero dynastyczna organizacja społeczeństw ludzkich pociągnęła za sobą dynamiczny rozwój państw, doprowadziła do intensyfikacji ich stosunków zewnętrznych i spowodowała kształtowanie się coraz bardziej kompleksowego, zaawansowanego systemu politycznego, regulującego ich stosunki. Było to jednak bardziej efektem rozwoju technologicznego i gospodarczego, aniżeli skutkiem powstania specyficznej organizacji politycznej.

Powstające w różnych częściach świata systemy poliarchii, w Azji, Europie, obu Amerykach, Afryce, w XIX i XX wieku przekształciły się ostatecznie 
w system globalny, w poliarchię obejmującą cały gatunek ludzki. W jego skład wchodzi wiele instytucji regulujących podstawowe stosunki społeczne w obrębie naszego rodzaju, podzielonego na terytorialne zjednoczenia polityczne, które rywalizują między sobą zarówno o porządek znanego świata, jak i przede wszystkim o zasoby konieczne do życia.

W świetle teorii poliarchii inaczej należy rozumieć termin ,internacjonalizacja". Oznacza on etap w procesie poliarchizacji, czyli ewolucji poliarchii, systemu politycznego regulującego funkcjonowanie całego gatunku ludzkiego w obrębie dostępnej mu przestrzeni w czasie ostatnich sześciu tysięcy lat. Jest to etap, który zapoczątkowany został w czasach rewolucji francuskiej, gdy państwa dynastyczne zaczęły dogorywać, i trwa nadal. Będzie trwał do momentu, gdy tożsamość narodowa utraci swoje znaczenie.

\section{Bibliografia}

Bloch M., Społeczeństwo feudalne, Warszawa 1981.

Brunner O., Land und Herrschaft, Wien 1966.

Creveld M., The Rise and Decline of the State, Cambridge 1999.

Dahl R., Polyarchy. Participation and Opposition, New Haven 1971.

Edbury P., Łaciński Wschód 1291-1669, [w] Historia krucjat, red. J. Ridley-Smith, Warszawa 2000.

Hooper N., Bennett M., Atlas sztuki wojennej w średniowieczu 768-1487, Warszawa 2004.

Internacjonalizacja polskich ośrodków politologicznych, red. T. Domański, A. Stępień-Kuczyńska, A. Frykowska, Łódź 2017.

Internacjonalizacja przedsiębiorstw: uwarunkowania, procesy, wyniki badań, red. B. Glinkowska-Krauze, Łódź 2016.

Kantorowicz E., Dwa ciała króla, Warszawa 2007.

Kennedy P., Mocarstwa świata, Warszawa 1994.

Kent J., The Internationalization of Colonialism. Britain, France and Black Africa, 1939-1956, Oxford 1992.

Kukułka J., Teoria stosunków międzynarodowych, Warszawa 2000.

Landwehr A., Die Erschaffung Venedig. Raum, Bevölkerung, Mythos 1570-1750, Paderborn 2007.

Rosand D., Mythos of Venice, Chapel Hill 2001.

Setton K., Catalan Domination of Athens 1311-1388, London 1975.

Skarzyński R., Anarchia i policentryzm, Białystok 2006.

Skarzyński R., Od statusu uczonego do funkcji ideokopiarki. Jak uniwersyteccy profesorowie daja się przekształcać $w$ środek polityczny i rujnuja własną dyscypline, powielając zachodnie wizje rzeczywistości międzynarodowej, [w:] Wokót teorii stosunków międzynarodowych, red. W. Mich, J. Nowak, Lublin 2012.

Skarzyński R., Stosunki międzynarodowe, system międzynarodowy i poliarchia, „Stosunki Międzynarodowe" 2010, nr 1-2.

Skarzyński R., Wajzer M., Staniucha T., Mind and Vision. Social Evolution and the Origins of the Political, „Social Evolution and History” 2016, nr 1.

Smil V., Energy in World History, Boulder 1994. 